\title{
Thermal and toxicological analysis of commercial polystyrene with recycled
}

\section{polystyrene}

\author{
Análise térmica e toxicológica de poliestireno comercial com poliestireno reciclado \\ Análisis térmico y toxicológico de poliestireno comercial con poliestireno reciclado
}

Recebido: 17/12/2021 | Revisado: 22/12/2021 | Aceito: 13/01/2022 | Publicado: 15/01/2022

Janiel Costa da Silva

ORCID: https://orcid.org/0000-0002-0876-9311 Federal Institute of Education, Science and Technology of Piauí, Brazil

E-mail: Janielcosta007@hotmail.com

Leandro Josuel da Costa Santos

ORCID: https://orcid.org/0000-0001-6051-2540

Federal Institute of Education, Science and Technology of Piauí, Brazil

E-mail: leandrosantos.educ@gmail.com

Sergio Marcelo Coelho Lustosa

ORCID: https://orcid.org/0000-0001-9980-0531

State University of Piauí, Brazil

E-mail: sergiomlustosa@gmail.com

Gesaiane de Andrade Silva

ORCID: https://orcid.org/0000-0001-8469-940X

State University of Piauí, Brazi

E-mail: gesaiane.ga@gmail.com

Gilvan Moreira da Paz

ORCID: https://orcid.org/0000-0002-6849-0320

Federal Institute of Education, Science and Technology of Piauí, Brazil

E-mail: gilvan@ifpi.edu.br

Deuzuita dos Santos Freitas Viana

ORCID: https://orcid.org/0000-0002-1902-6505

State University of Maranhão, Brazil

E-mail: deuzuitasfv@gmail.com

Vicente Galber Freitas Viana

ORCID: https://orcid.org/0000-0002-3863-6974

Federal Institute of Education, Science and Technology of Piauí, Brazil

E-mail: galber@ifpi.edu.br

\begin{abstract}
The purpose of this work was to characterize, through analytical methods, the physicochemical and toxicological properties between commercial polystyrene and recycled polystyrene. The characterization of the respective products was started with X-Ray Fluorescence (FRX), Thermogravimetric Analysis (TGA) and Differential Scanning Calorimetry (DSC). The in vitro analysis of toxicity in microcrustacean Artemia salina was carried out. The FRX analyzes indicated the presence of chlorine and bromine in the commercial PS. It was observed that recycled PS presents greater thermal stability when compared to commercial PS. No toxicity results were observed for the two types of samples cited in this research.
\end{abstract}

Keywords: Polymer; Thermal stability; Toxicity.

\section{Resumo}

A finalidade do presente trabalho foi caracterizar através de métodos analíticos as propriedades físico-químicas e toxicológica entre o poliestireno comercial e o poliestireno reciclado. Iniciou - se a caracterização dos respectivos produtos com Fluorescência de Raios X (FRX), Análise Termogravimétrica (TGA) e Calorimetria Exploratória Diferencial (DSC). Fez - se a analise in vitro da toxicidade em microcrustáceo Artemia salina. As análises de FRX indicaram a presença de cloro e bromo no PS comercial. Observou-se que o PS reciclado apresenta maior estabilidade térmica, quando comparado ao PS comercial. Nenhum resultado de toxicidade foi observado para os dois tipos de amostras citadas nesta pesquisa.

Palavras-chave: Polímero; Estabilidade térmica; Toxicidade.

\section{Resumen}

El propósito de este trabajo fue caracterizar, a través de métodos analíticos, las propiedades fisicoquímicas y toxicológicas entre el poliestireno comercial y el poliestireno reciclado. La caracterización de los respectivos productos se inició con Fluorescencia de Rayos X (FRX), Análisis Termogravimétrico (TGA) y Calorimetría 
Diferencial de Barrido (DSC). Se realizó el análisis in vitro de toxicidad en microcrustáceo Artemia salina. Los análisis de FRX indicaron la presencia de cloro y bromo en el PS comercial. Se observó que el PS reciclado presenta una mayor estabilidad térmica en comparación con el PS comercial. No se observaron resultados de toxicidad para los dos tipos de muestras citados en esta investigación.

Palabras clave: Polímero; Estabilidad térmica; Toxicidad.

\section{Introduction}

Several sectors have sought alternatives in order to reduce the environmental impacts resulting from industrial production processes, as well as from the use of polymeric products and their disposal (Jesus et al. 2019).

In addition, with the inherent popular concerns about the recycling theme, followed - the consequent technological innovations that sought, from scientific analyzes and methodologies, to align ideas in search of viable solutions to solve the recurrent problems of the high level of consumption and production of waste of the current society (Araújo et al. 2021).

Plastics cause a lot of damage to the environment, as they take hundreds of years to undo, causing many problems for people and the environment (Da Cruz et al. 2020). But, according to Carvalho \& Motta (2019), polystyrene (PS) can be reused from discarded waste, reducing the environmental impact of disposing of this difficult-to-decompose polymer and also improving the properties of new or modified materials in which it is incorporated.

Polystyrene is classified as one of the most used thermoplastics by the polymer processing industry. PS is characterized by its transparency, ease of processing, thermal stability, low density, high modulus of elasticity, excellent electrical properties and low cost (Luna et al. 2015). Polystyrene is a polymer that gives rise to microparticles with a hydrophobic surface, by polymerizing styrene at high temperatures $\left(80^{\circ} \mathrm{C}\right)$ (Severino et al. 2011).

As it is a petroleum-derived plastic, it can be recycled, that is, after its first application, it can return to the industry and be transformed into another product for the civil construction, automotive, furniture segments, packaging for cleaning products, beverages, among others (Araújo et al. 2021). In this sense, polystyrene is the pioneer polymer among thermoplastics, among its main applications are packaging for the food industry, especially disposable cups (Ferreira et al. 2020).

Among the main solid waste observed in the composition of Brazilian urban waste, disposable cups occupy a prominent position, even more considering the prolonged time of decomposition in the environment and the difficulties in recycling the waste, in view of the minimum return from its disposal process (Quirino et al. 2018).

Thus, the objective of this work was to compare the thermal behavior and toxicity of commercial and recycled polystyrene from disposable cups.

\section{Methodology}

\subsection{Materials}

The commercial polystyrene (PS) solid, granulated with $0.25 \mathrm{~mm}$ to $2 \mathrm{~mm}$ in diameter, with density ranging from 0.009 to $0.016 \mathrm{~g} / \mathrm{cm} 3$ and particle size ranging from 1.23 to $2.00 \mathrm{~mm}$. Figure 1, was donated by the Soferro LTDA group, having its origin from NewPop do Brazil Chemical Industry and acetone PA (Contemporary Chemical Dynamics LTDA). 
Figure 1. Grainy commercial PS (a) and 400x magnified image (b).

(a)

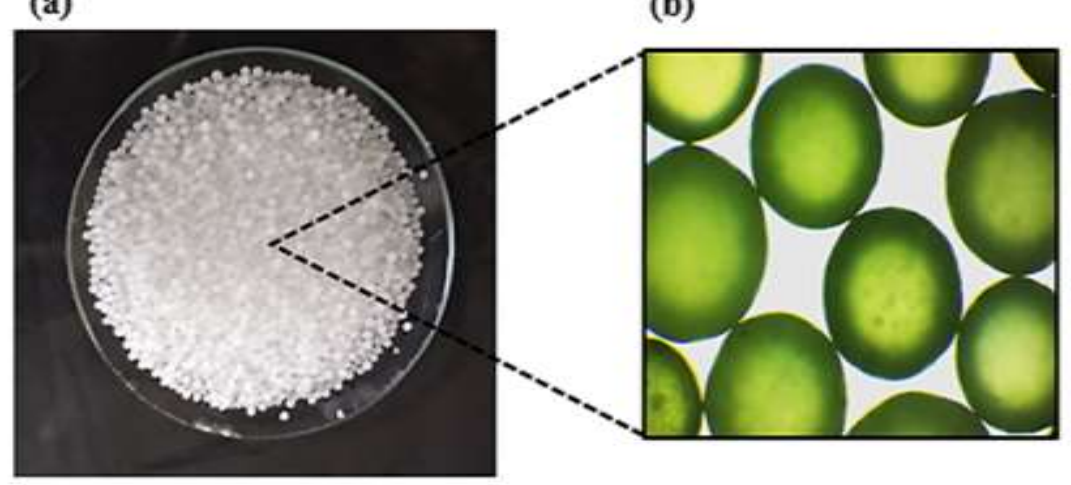

Source: Authors.

\subsection{PS recycling from disposable cups}

The disposable cups were obtained from the Federal Institute of Education, Science and Technology of Piauí - IFPI, Teresina central campus; they were properly washed and dried for 24 hours in an oven at $40^{\circ} \mathrm{C}$. Then, the cups were immersed in acetone to release the gaseous molecules and placed in a desiccator for solvent evaporation. After the solvent evaporation, the material was ground in a knife grinding mill and, finally, sieved in a 24-mesh sieve. This process serves to reduce the granulometry of the sample, as can be seen in Figure 2.

Figure 2. recycled PS from disposable cups (a) and 400x magnified image (b).

(a)

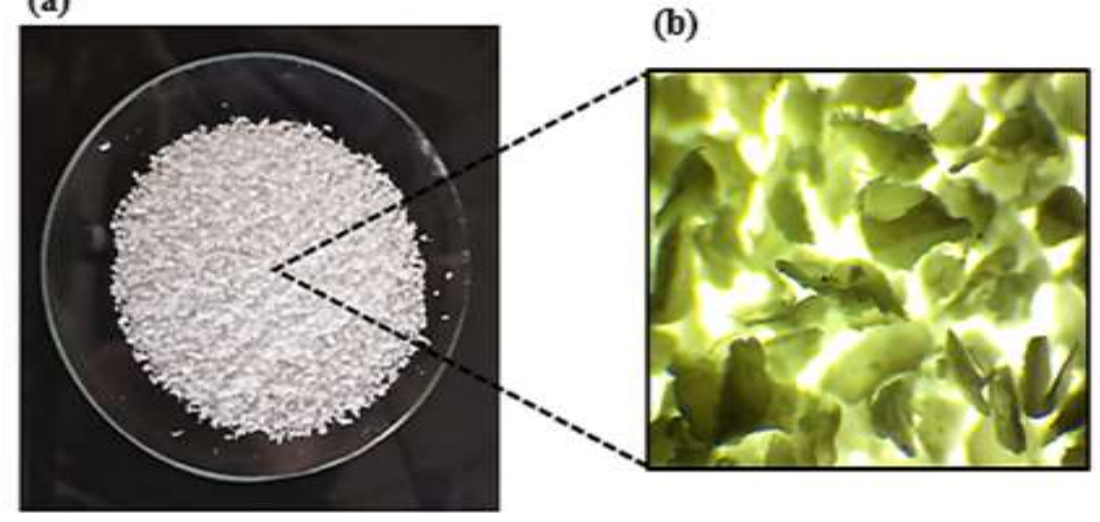

Source: Authors.

To characterize the materials in this work, was used an X-ray fluorescence spectrometer (FRX), model Epsilon 3 - XL from Panalytical, using omnian mode, in an atmosphere of atmospheric air and nitrogen gas.

The thermogravimetric analysis (TGA) was performed using equipment from the Shimadzu brand, model TGA-51. The analysis conditions were test temperature range from $25^{\circ} \mathrm{C}$ to $800^{\circ} \mathrm{C}$, heating rate $10^{\circ} \mathrm{C}$. min ${ }^{-1}$ and nitrogen atmosphere at $50 \mathrm{~mL} \cdot \mathrm{min}^{-1}$ in platinum sample holder.

The DSC measurement was performed in Shimadzu brand equipment - Model DSC 60 PLUS under the following conditions: test temperature range from $25^{\circ} \mathrm{C}$ to $600^{\circ} \mathrm{C}$, heating rate of $10^{\circ} \mathrm{C} \cdot \mathrm{min}^{-1}$ in atmosphere of nitrogen at $50 \mathrm{~mL} \cdot \mathrm{min}{ }^{-1}$. Aluminum sample holder was used. 
The determination of the ash content was carried out using the procedure applied by Santos et al. (2017) with adaptations, which consists in the determination of weight loss through heating at $600^{\circ} \mathrm{C}$ in a muffle. For this test, 2 crucibles were previously heated, dried and then weighed on an analytical balance. In each crucible $4.5 \mathrm{~g}$ of commercial and recycled PS samples were weighed, then the crucibles were transferred to a muffle at $600^{\circ} \mathrm{C}$ and left until the residue turned white or light gray.

The toxicity test with Artemia salina was carried out at the Physical - Chemistry Laboratory of the Federal Institute of Piauí - IFPI, Teresina Central campus. For this test, was used the method described by Meyer et al. (1982) with adaptations. The cysts were incubated in sea water in an incubation chamber for 24 hours under constant lighting (20-watt lamps) at an average temperature of $28^{\circ} \mathrm{C} \pm 2^{\circ} \mathrm{C}$. The tests were carried out in quintuplicate where 10 nauplii were transferred to each test tube containing sea water at a concentration of $1000 \mu \mathrm{g} / \mathrm{mL}$ of the material to be tested Meyer et al. (1982) and Sousa et al. (2021) with adaptations.

For the negative control, only the saline mixture was used, and for the positive control a potassium dichromate solution $\left(\mathrm{K}_{2} \mathrm{Cr}_{2} \mathrm{O}_{7}\right)$ at a concentration of $1000 \mu \mathrm{g} / \mathrm{mL}$. The percentage of dead nauplii after the 24-hour period was checked in order to estimate whether there was a mortality of $50 \%$ of these nauplii.

\section{Results and discussion}

\subsection{Characterization by X-ray fluorescence spectrometry (FRX)}

The x-ray fluorescence analysis, Table 1, presents the results of the inorganic components present in both commercial and recycled PS.

Table 1. Chemical composition of the inorganic part of commercial PS e recycled PS by FRX.

\begin{tabular}{c|cc}
\hline \multirow{2}{*}{ Components } & \multicolumn{2}{|c}{ Concentration, in (\%) } \\
\cline { 2 - 3 } & commercial PS & recycled PS \\
\hline $\mathbf{A l}$ & 0,407 & 3,344 \\
$\mathbf{S i}$ & 2,917 & 7,504 \\
$\mathbf{P}$ & 2,341 & 2,813 \\
$\mathbf{C l}$ & 0,384 & $*$ \\
$\mathbf{F e}$ & 0,119 & 1,247 \\
$\mathbf{Z n}$ & 1,245 & 3,231 \\
$\mathbf{B r}$ & 79,679 & $*$ \\
$\mathbf{A g}$ & 12,908 & 12,531 \\
$\mathbf{S n}$ & $*$ & 2,255 \\
\hline
\end{tabular}

* Components not detected. Source: Authors.

The results showed levels of phosphorus, chlorine, and bromine components in the commercial PS sample. The presence of these elements indicates that there was the introduction of phosphorous and/or halogenated flame retardants during the manufacture of PS, however, the high content of bromine detected reveals the incorporation of halogenated flame retardants. Corroborating with Hirayama et al. (2015) in which he states in his studies that PS was added with compounds based on chlorine, bromine and phosphorus to prevent the spread of flames.

The presence of $\mathrm{Si}$ in both commercial and recycled PS samples may be related to some possible contamination during the tests or to some experimental error of the equipment, since $\mathrm{Mg}(\mathrm{Z}=12), \mathrm{Al}(\mathrm{Z}=13), \mathrm{Si}(\mathrm{Z}=14)$ and $\mathrm{P}(\mathrm{z}=15)$ are neighboring elements in the periodic table. This fact can cause superposition of spectral lines of the elements, due to the proximity of the excitation energies of the electrons, making the analysis difficult. This result is in agreement with the one found by (Fernandes, 2009). 
When comparing with recycled PS, it is noticed the absence of halogenated components. This is due to the treatment carried out in the PS recycling process using acetone as a solvent, which caused the release of gas molecules present in the composition of disposable cups.

Regarding the high titanium content detected in the recycled PS sample, Turner (2021) reports that the detection of titanium reflects the common use of $\mathrm{TiO}$ as a pigment that is mixed or molded into the material to provide a high refractive index and chemical stability.

\subsection{Thermal characterization}

\subsubsection{Thermogravimetric Analysis (TGA)}

Figure 3 shows the thermogravimetric analysis of commercial and recycled PS, where commercial PS presented three mass loss events. The first event occurred between 110 and $170^{\circ} \mathrm{C}$ with a mass loss of approximately $2.1 \%$. The second event occurred between 290 and $450^{\circ} \mathrm{C}$ with a mass loss of approximately $93 \%$. The third event occurred between 470 and $580^{\circ} \mathrm{C}$ with a mass loss of approximately $2.4 \%$.

Figure 3. TGA curve of commercial and recycled PS.

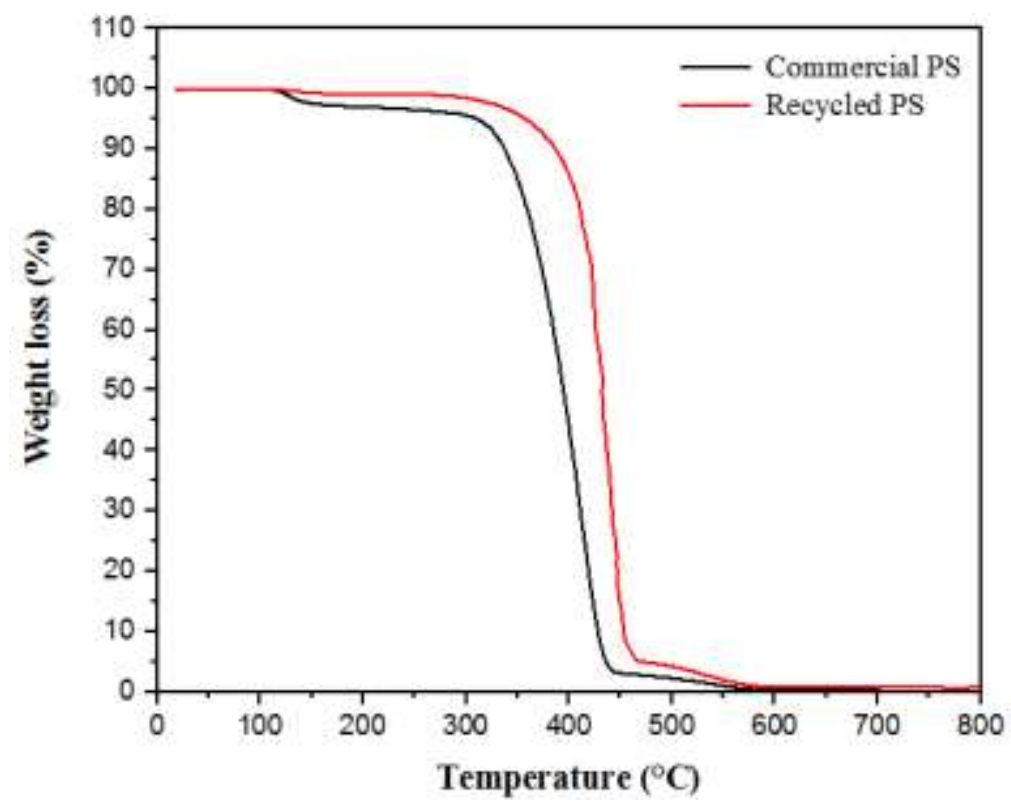

Source: Authors.

Table 2. Results of thermogravimetric analysis (TG) of commercial PS and recycled PS.

\begin{tabular}{cccc}
\hline Samples & Thermal Event & $\mathbf{T}\left({ }^{\circ} \mathbf{C}\right)$ & $\mathbf{m}(\boldsymbol{\%})$ \\
\hline \multirow{2}{*}{ Commercial PS } & 1 & $110,0-170,0$ & 2,143 \\
& 2 & $290,0-450,0$ & 92,851 \\
& 3 & $470,0-580,0$ & 2,435 \\
\hline \multirow{2}{*}{ Recycled PS } & 1 & $70,0-160,0$ & 0,744 \\
& 2 & $300,0-470,0$ & 92,421 \\
& 3 & $480,0-590,0$ & 3,543 \\
\hline
\end{tabular}

Legend: $\Delta \mathrm{T}\left({ }^{\circ} \mathrm{C}\right)$ temperature range, $\Delta \mathrm{m}(\%)$ loss of mass. Source: Authors.

The recycled PS also presented three mass loss events, where the first loss event was not significant (less than $1 \%$ ). The second event occurred between 300 and $470^{\circ} \mathrm{C}$ with a mass loss of approximately $93 \%$. The third event occurred between 480 and 
$590^{\circ} \mathrm{C}$ with a loss of approximately $4 \%$ of the mass. Table 2 shows the values related to temperature variation with the respective mass loss in the events present in the degradation of commercial and recycled PS samples.

According to the tests performed by Botan et al. $(2011,2012)$ and Moraes et al. (2014), commercial PS has a slight loss of mass around $115^{\circ} \mathrm{C}$. This loss is probably related to the loss of water present in the polystyrene structure. Between 120 $360^{\circ} \mathrm{C}$, the mass remains constant and, from this point, the degradation of the polymer chains occurs until approximately $443^{\circ} \mathrm{C}$, a temperature at which practically all the material has already been consumed. However, according to studies carried out by Jesus et al. (2019), the thermal behavior of recycled PS formed from post-consumer PS, hot pressed, showed thermal stability up to about $350^{\circ} \mathrm{C}$.

\subsubsection{Thermogravimetric Derivative Analysis (DrTG)}

Through the analysis of the DrTG curve of commercial and recycled PS, Figure 4, it was possible to observe that there was a displacement of the peak referring to recycled PS to a higher temperature in relation to commercial PS. At the same time, it can be noted that there is no noticeable change in the thermal degradation mechanism between the samples, as the first derivative curves are similar in shape. Furthermore, it can be noted that recycled PS has a more symmetrical appearance in the first derivative curve when compared to commercial PS.

According to Jesus et al. (2019) the thermal degradation of recycled PS is in the range of $410^{\circ} \mathrm{C}$, this degradation being attributed to the breaking of bonds in saturated and unsaturated carbon in the polystyrene. In addition, Nunes et al. (2016) reports in their analysis that recycled PS presents a thermogravimetric curve with only one degradation step, with a pronounced slope of the curve and with a variation between the initial and final degradation temperature of approximately $50^{\circ} \mathrm{C}$.

Figure 4. DrTG curve of commercial and recycled PS.

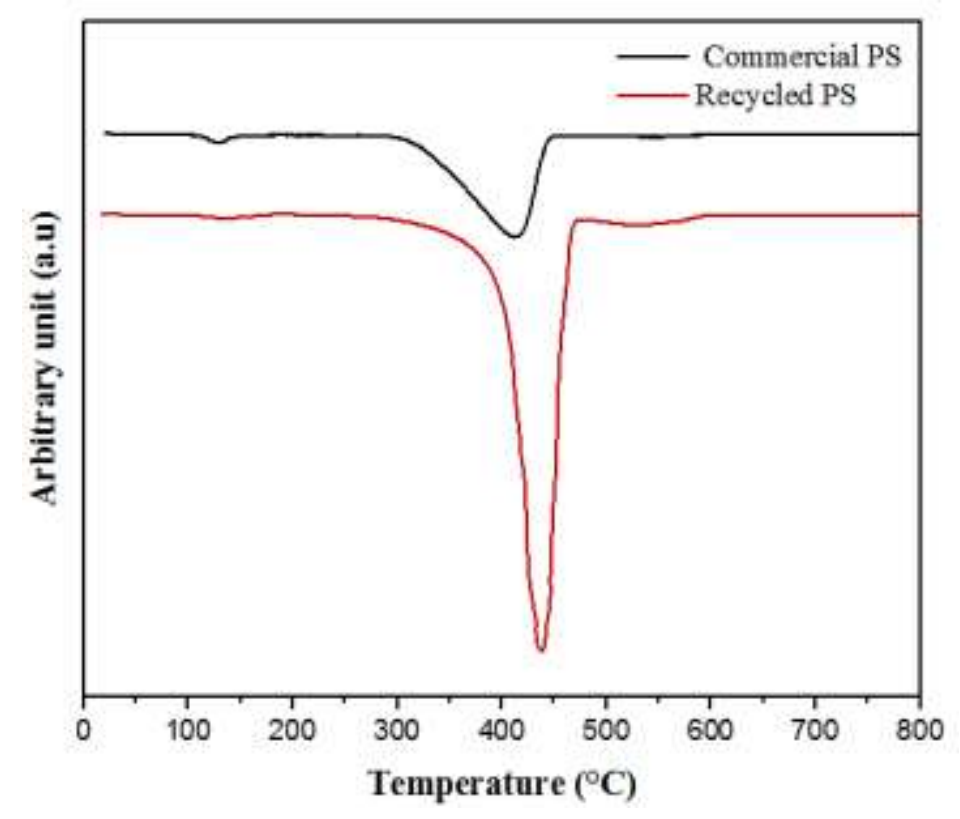

Source: Authors.

Figure 5 shows the DSC curves of commercial and recycled PS where they presented a single endothermic event, however, recycled PS showed a peak shift to the right at $\square 433^{\circ} \mathrm{C}$ compared to commercial PS, which peaked at $\square 420^{\circ} \mathrm{C}$. In addition, there is a significant increase in temperature related to the maximum decomposition of recycled PS. Table 3 shows the numerical values that justify the graphic behavior in Figure 5. 
Figure 5. DSC curve of commercial and recycled PS.

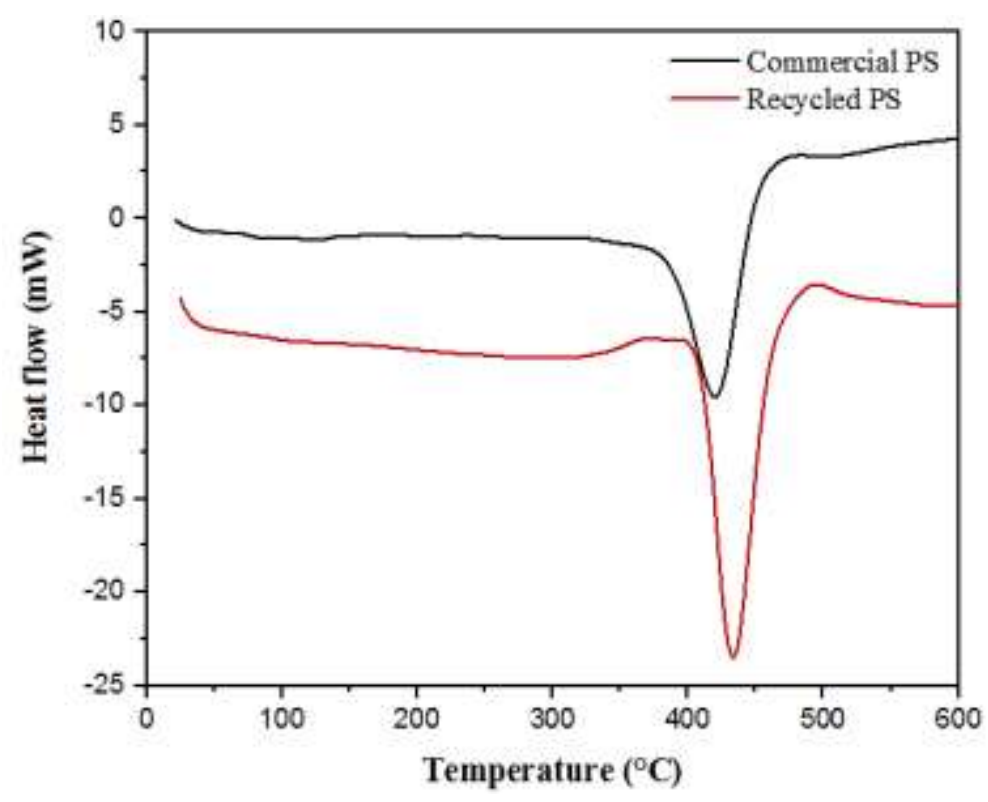

Source: Authors.

Table 3. Numerical values of physical properties obtained by DSC of commercial and recycled PS.

\begin{tabular}{ccccc}
\hline Samples & $\mathbf{T}_{\text {onset }}\left({ }^{\circ} \mathbf{C}\right)$ & $\mathbf{T}_{\text {endset }}\left({ }^{\circ} \mathbf{C}\right)$ & $\mathbf{T}_{\text {peak }}\left({ }^{\circ} \mathbf{C}\right)$ & $\mathbf{H}_{(\mathrm{J} / \mathrm{g})}$ \\
\hline Commercial PS & 389,36 & 451,52 & 419,94 & 754,65 \\
Recycled PS & 410,75 & 462,68 & 433,45 & 784,51 \\
\hline
\end{tabular}

Legend: Tonset $\left({ }^{\circ} \mathrm{C}\right)$ extrapolated initial temperature, Tendset $\left({ }^{\circ} \mathrm{C}\right)$ extrapolated final temperature, Tpeak $\left({ }^{\circ} \mathrm{C}\right)$ peak temperature, $\Delta \mathrm{H}(\mathrm{J} / \mathrm{g})$ enthalpy variation. Source: Authors.

According to Jesus et al. (2019), commercial PS presents a single event in the region of $420^{\circ} \mathrm{C}$, characteristic of the main volatile component produced from the thermal degradation of PS, which is the styrene monomer. Furthermore, Silva et al., (2020) reports that the peak in the region of $430^{\circ} \mathrm{C}$ is correlated with evaporation of volatile products, followed by polymer degradation.

According to Neto et al. (2020), ashes are the inorganic residue that remains after the burning of organic matter, they allow quantifying the mineral fraction incorporated into the polymer matrix. After heating to $600^{\circ} \mathrm{C}$, the ash content for commercial PS was $3.49 \%$ and $7.16 \%$ for recycled PS.

Recycled PS has a higher ash content than commercial PS (Table 4), due to the greater number of agents incorporated by the industry for the production of disposable cups, in which they were used for recycling PS. An analysis will later be carried out by atomic absorption to determine its composition.

Table 4. Test of ash content of recycled and commercial PS.

\begin{tabular}{lcc}
\hline & recycled PS & commercial PS \\
\hline crucible dough, $(\mathrm{g})$ & 18,0280 & 18,5481 \\
mass (crucible + sample), (g) & 22,5550 & 23,0750 \\
sample mass, (g) & 4,527 & 4,527 \\
dough (ash), (g) & 0,0716 & 0,0349 \\
ash content, $(\%)$ & 1,58 & 0,77 \\
\hline
\end{tabular}

Source: Authors. 
In addition, in accordance with ASTM (2013) which addresses the standard test method for ash content in plastics, the standard reports that these incineration procedures are only used to quantify residual solids in the polymer and cannot be used to identify the individual chemical components of the ash, qualitatively.

Regarding the toxicity test, Table 5 presents the results of the toxicity of commercial PS added in an aqueous solution of DMSO $1 \%$ in sea water $\mathrm{v} / \mathrm{v}$ for $24 \mathrm{~h}$, at a concentration of $1000 \mu \mathrm{g} / \mathrm{mL}$ of commercial PS, it could be noted that in the quintuplicate, mortality corresponded to $2 \%$ in all the nauplii used in the experiment, while in Table 6 , which brings data on the toxicity of recycled PS, was observed the absence of mortality.

Table 5. Toxicity of commercial PS.

\begin{tabular}{lcccccccc}
\hline Samples & $\mathbf{0 1}$ & $\mathbf{0 2}$ & $\mathbf{0 3}$ & $\mathbf{0 4}$ & $\mathbf{0 5}$ & $\overline{\boldsymbol{x}}$ & $\mathbf{C N}$ & $\mathbf{C P}$ \\
\hline $\mathbf{n}$ & 10 & 10 & 10 & 10 & 10 & 10 & 10 & 10 \\
$\mathbf{n}_{-}$ & 0 & 1 & 0 & 0 & 0 & 0,2 & 0 & 10 \\
$\mathbf{n}_{-}(\boldsymbol{\%})$ & 0 & 10 & 0 & 0 & 0 & - & 0 & 100 \\
\hline
\end{tabular}

Legend: $\mathrm{n}=$ number of Nauplii; $\mathrm{n}_{-}=$deaths; $\mathrm{n}_{-}(\%)=$ percentage; $\mathrm{x}^{-}=$mean; $\mathrm{CN}=$ negative control; $\mathrm{CP}=$ positive control. Source: Authors.

Table 6. Toxicity of recycled PS.

\begin{tabular}{lcccccccc}
\hline Samples & $\mathbf{0 1}$ & $\mathbf{0 2}$ & $\mathbf{0 3}$ & $\mathbf{0 4}$ & $\mathbf{0 5}$ & $\overline{\boldsymbol{x}}$ & $\mathbf{C N}$ & $\mathbf{C P}$ \\
\hline $\mathbf{n}$ & 10 & 10 & 10 & 10 & 10 & 10 & 10 & 10 \\
$\mathbf{n}_{-}$ & 0 & 0 & 0 & 0 & 0 & 0 & 0 & 10 \\
$\mathbf{n}_{-}(\boldsymbol{\%})$ & 0 & 0 & 0 & 0 & 0 & - & 0 & 100 \\
\hline
\end{tabular}

Legend: $\mathrm{n}=$ number of Nauplii; $\mathrm{n}_{-}=$deaths; $\mathrm{n}_{-}(\%)=$ percentage; $\mathrm{x}^{-}=$mean; $\mathrm{CN}=$ negative control; $\mathrm{CP}=$ positive control. Source: Authors.

The solution with recycled PS revealed a non-toxic character against Artemia salina. Despite the occurrence of 2\% mortality in the commercial PS solution, it is not characterized as a toxic material at this concentration, Meyer et al. (1982) reported that when the mortality of these nauplii is less than $50 \%$ for a concentration of $1000 \mu \mathrm{g} / \mathrm{mL}$ of the material to be tested, this material is considered non-toxic.

Studies developed by Bergami et al. (2016), indicated the absence of toxicity at different concentrations $(0,5,10,25$, 50 and $100 \mu \mathrm{g} / \mathrm{ml}$ ) of polystyrene nanoparticles. Using the aforementioned methodology with a concentration of $1000 \mu \mathrm{g} / \mathrm{mL}$ of PS there was no occurrence of mortality with a value greater than 50\%. Therefore, the minimum mortality rate observed may be associated with the presence of bromine identified in the FRX analysis.

\section{Conclusion}

The use of the recycling process was important in significantly reducing contaminants. The FRX analysis showed the presence of chlorine and bromine components in the commercial PS sample, while in the recycled PS sample the mentioned components were eliminated. Recycled PS showed greater thermal stability compared to commercial PS. The toxicity test showed that both commercial and recycled PS do not present toxicity against Artemia salina, which does not characterize the occurrence of a dose-dependent effect.

Due to technological advances and the emergence of lines of research directed to biomedical areas, there is a need for research aimed at the application of polymers, such as polystyrene associated with metallic nanoparticles aimed at tissue regeneration and in vivo testing with PS acting as an agent for controlled drug release. 


\section{Acknowledgment}

We would like to express our thanks to the SOFERRO group for the supplying of the polystyrene.

\section{References}

Araújo, J. H. bernardino de, \& Silva, V. de S. (2021). Analysis of the behavior of the digestive tract microorganisms of tenebrio molitor linnaeus and zophobas morio fabricius in culture media containing expanded polystyrene. Brazilian Journal of Developement, 7(5), 45917-45923.

ASTM. (2013). American Society For Testing And Materials (ASTM). D5630 : Standard Test Method for Ash Content in Plastics. United States of America, 2013 .

Bergami, E., Bocci, E., Vannuccini, M. L, Monopoli, M., Salvati, A., Dawson, K. A., \& Corsi, I. (2016). Nano-sized polystyrene affects feeding, behavior and physiology of brine shrimp Artemia franciscana larvae. Ecotoxicology and Environmental Safety, 123, 18-25. 10.1016/j.ecoenv.2015.09.021.

Botan, R., Nogueira, T. R., Lona, L. M. F., \& Wypych, F. (2011). Síntese e Caracterização de Nanocompósitos Esfoliados de Poliestireno-Hidróxido Duplo Lamelar Via Polimerização. Polímeros, 21(1), 34-38.

Botan, R., Nogueira, T. R., Wypych, F., \& Lona, L. M. F. (2012). In situ synthesis, morphology, and thermal properties of polystyrene-MgAl layered double hydroxide nanocomposites. Polymer Engineering and Science, 52(8), 1754-1760. 10.1002/pen.23122.

Carvalho, C. H. R., \& Motta, L. A. C. (2019). Estudo de concreto com poliestireno expandido reciclado. Revista IBRACON de Estruturas e Materiais, 12, 1390-1407. 10.1590/S1983-41952019000600010.

Da Cruz, B. D. S. M., de Souza, M. L., \& de Freitas, A. B. R. (2020). Reutilização de plásticos: uma forma de articular a educação ambiental e o ensino de polímeros através de uma feira de ciências. Revista Eletrônica Perspectivas da Ciência e Tecnologia. 12.

Fernandes, G. A. (2009). Desenvolvimento de espumas semi-rígidas de poliestireno com propriedades oxi-biodegradáveis. Universidade Federal de Santa Catarina.

Ferreira, K. B., Ferreira, J. C., Andrade, C. R., Teixeira, D. E., Garcia, L. F. A., Guimarães, Í. L., Silva, T. E., \& Machado, D. K. F. (2020). Impacto da adiação de poliestireno na composição de painéis de bagaço de cana-de-acúcar. Scientia Forestalis, 48(126), 1-13. 10.18671/SCIFOR.V48N126.20

Filho, G. R., Assunção, R. M. N. de, Marques, F. C. A., Corrente, N. G., \& Meireles, C. da S. (2008). Síntese de poliestireno sulfonado para aplicações no tratamento de água produzido a partir de copos e bandejas descartadas de poliestireno. Quimica Nova, 31(8), $2004-2008$.

Hirayama, D., \& Saron, C. (2015). Characterisation of recycled acrylonitrile-butadiene-styrene and high-impact polystyrene from waste computer equipment in Brazil. Waste Management and Research, 33(6), 543-549. 10.1177/0734242X15584845.

Jesus, L. C. C. de, Luz, S. M. da, Leão, R. M., Zattera, A. J., \& Amico, S. C. (2019). Comportamento térmico de compósitos de poliestireno reciclado reforçado com celulose de bagaço de cana. Revista Materia, 24(3). 10.1590/s1517-707620190003.0736.

Luna, C. B. B., Silva, D. F. da, Araújo, E. M., Melo, T. J. A. de, \& Oliveira, A. D. de. (2015). Estudo do comportamento mecânico, termomecânico e morfológico de misturas de poliestireno/composto de borracha reciclada (SBR). Revista Materia, 20(2), 322-334. 10.1590/S1517-707620150002.0033.

Meyer, B. N., Ferrigni, N. A., Putnam, J. E., Jacobsen, L. B., Nichols, D. E., \& Mclaughlin, J. L. (1982). Brine Shrimp: A Convenient General Bioassay for Active Plant Constituents. Planta Medica, 45, 31-34.

Moraes, S. B. de, Botan, R., \& Lona, L. M. F. (2014). Síntese e caracterização de nanocompósitos de poliestireno/hidroxissal lamelar. In Quim. Nova (Vol. 37, Issue 1).

Neto, A. G. V. de C., Santos, D. I. dos, Rissato, S. R., Saeki, M. J., Favaro, S. L., Radovanovic, E., \& Pellosi, D. S. (2020). Avaliação das propriedades físicos, química e mecânicas de filmes de amido/PVA/argila/benonita modificados com metacrilato de glicidila. Revista Materia, 25(03), 1-15.

Nunes, M. A. B. S., Galvão, L. S., Ferreira, T. P. M., Luiz, E. J. F. T., Bastos, Y. L. M., \& Santos, A. S. F. (2016). Reprocessability of high impact polystyrene/clay nanocomposites in extrusion. Polymer Degradation and Stability, 125, 87-96. 10.1016/j.polymdegradstab.2015.12.013.

Quirino, C. A. de S., \& Ramos, R. D. C. de A. (2018). Ações sustentáveis e suas implicações no trabalho: uma análise acerca do uso de copos descartáveis no colegiado de engenharia elétrica (cenel) na univasf. Revista Multidisciplinar e de Psicologia, 12(41), $390-413$.

Santos, F. K. dos, Sebatke, B. F. dos S., Bertolazo, M. L., \& Mattanna, P. (2017). Extração da papaína e produção de bioplástios para tratamento alternativo de feridas. Revista Eletrônica Biociências, Biotecnologia e Saúde, 9(18), 51-59.

Severino, P., Santana, M. H. A., Pinho, S. C., \& Souto, E. B. (2011). Polímeros Sintéticos Biodegradáveis: Matérias-primas e Métodos de Produção de Micropartículas para uso em Drug Delivery e Liberação Controlada. Polímeros, 21(4), 286-292.

Silva, A. M. P. da, Margalho, D. E., \& Correia Junior, D. S. (2020). Effect of adding endocarp residue tucumã (Astrocaryum aculeatum) in high impact polystyrene (hips). Revista Materia, 25(3), 1-10. 10.1590/s1517-707620200003.1131.

Sousa, M. V. dos S., Pereira, T. F., Macêdo, H. R. A. de, \& Macêdo, M. de O. C. (2021). Análise de testes toxicológicos Artêmia Salina e Allium cepa em membranas de quitosana com líquido da Castanha do Cajú (LCC). Brazilian Journal of Developement, 7(4), 33902-33909.

Turner, A. (2021). Polystyrene foam as a source and sink of chemicals in the marine environment: An XRF study. Chemosphere, 263(128087), 1-6. 10.1016/j.chemosphere.2020.128087 